\title{
Correction to: Preparation of high-purity magnesium-ammonium-phosphate fertilizer using sea bittern and industrial waste streams
}

\author{
Rahul J. Sanghavi ${ }^{1,2} \cdot$ Rakesh Dobariya $^{1} \cdot$ Sameer Bhatti ${ }^{1} \cdot$ Arvind Kumar $^{1}$ (D) \\ Published online: 28 January 2021 \\ (C) Springer-Verlag GmbH Germany, part of Springer Nature 2021
}

Correction to: Environmental Science and Pollution Research (2020) 27:7720-7728

https://doi.org/10.1007/s11356-019-07445-4

Additional affiliation for the 1 st Author shown in this paper.

Publisher's note Springer Nature remains neutral with regard to jurisdictional claims in published maps and institutional affiliations.

The online version of the original article can be found at https://doi.org/ 10.1007/s11356-019-07445-4

Arvind Kumar

arvind@csmcri.res.in

1 Salt and Marine Chemicals Division, Council of Scientific and Industrial Research, CSIR-Central Salt and Marine Chemicals Research Institute, G. B. Marg, Bhavnagar 364002, India

2 P.D. Patel Institute of Applied Sciences, Charotar University of Science \& Technology, Changa, Anand, Gujarat 388421, India 